\title{
Improvement of forage lands in Central Non-Black Earth Zone of Russia by using some integrated approaches
}

\author{
Nikolay Vasilievich Aldoshin ${ }^{1^{*}}$, Alexander Sergeevich Vasiliev ${ }^{2}$, Andrey Vasilievich Kudryavtsev ${ }^{2}$, \\ Anton Sergeevich Firsov ${ }^{2}$, Vyacheslav Viktorovich Golubev ${ }^{2} \&$ Lyudmila Yuryevna Vasilieva $^{2}$ \\ ${ }^{1}$ Russian State Agrarian University - Moscow Timiryazev Agricultural Academy, Moscow 127 550, Russia \\ ${ }^{2}$ Tver State Agricultural Academy, Tver 170 904, Russia \\ *Email: naldoshin@yandex.ru
}

\section{ARTICLE HISTORY}

Received: 01 June 2020

Accepted: 18 October 2020

Published: 01 January 2021

\section{KEYWORDS}

Monitoring

Technology

Grass mixtures

Tillage

Sowing

Field germination rate

Yield

\begin{abstract}
In an activity system aimed at creation of high-quality fodder base for animal agriculture, crop science plays the main role. It facilitates the increase in the productivity of forage crops, which guarantees the relevance of efficiency studies and the developed technologies for improving forage lands. The research was aimed at studying the impact of integrated approaches to improving forage lands in the Central Non-Black Earth Zone. The objectives of the research were as follows: to present a methodology for monitoring agricultural fields for the subsequent improvement of forage lands; to develop an efficient technology for improving forage lands using modern mechanization means; to study the productivity of different grass mixtures when implementing various options for soil cultivation. Based on the results of three years of theoretical and experimental research, a technological scheme for fodder land improvement (including technical processes) was compiled: monitoring of fields, preparation of grass mixtures and mineral fertilizers, preparation and tuning of machine-tractor aggregates, assessment of the yield of two-time grass cutting and secondary monitoring of fields. The proposed technology included several levelling technological operations (including levelling of hillocks), operations for the preparation of the seedbed and the seed material in the form of grass mixtures and mineral fertilizers and subsequent strip sowing. It has been established that when improving fodder lands as well as the quality of soil preparation, the prevalence of milling created more favorable conditions for increasing productivity of perennial grasses compared to disking.
\end{abstract}

\section{Introduction}

Fodder lands occupy about 3.4 bln ha in the world, including more than $92 \mathrm{mln}$ ha in the Russian Federation. The importance of forage production lies in solving the problem of rational use of natural resources in agriculture, ensuring the balance of agricultural landscapes, the structure of sown areas, crop rotations, optimization of crop production, agriculture and animal husbandry. Increasing the productivity of fodder land is one of the most critical tasks of agricultural production, dictated by the need to maximize the productivity of the animals, in part through increasing the cost recovery for each fodder unit (1-8). It should also be noted that over $2 / 3$ of haylands and pasture fields of the Central Non-Black Earth Zone in the Russian Federation are degrading, which is due to the deterioration of the flora, the prevalence of low-value plant species, the formation of a long-term sod layer that is resistant to mechanical stresses and the disruption of the air and water regime of the surface soil (1). This condition of forage lands requires the development of new approaches for their use, based on the analysis of their initial and expected characteristics after improvement (botanical, environmental, agrochemical, technical, economic and others). It is known, for example, that surface improvement of pasture fields increases yield by a factor of 1.5-2.0 (9).

Studies on the use of integrated approaches to improve forage land are mainly theoretical, with no practical projection onto agriculturally used areas, which requires special experimental studies and

(C) Aldoshin et al (2021). This is an open-access article distributed under the terms of the Creative Commons Attribution License, which permits unrestricted use, distribution and reproduction in any medium, provided the original author and source are credited (https://creativecommons.org/licenses/by/4.0/).

To cite this article: Aldoshin N V, Vasiliev A S, Kudryavtsev A V, Firsov A S, Golubev V V, Vasilieva L Y. Improvement of forage lands in Central Non-Black Earth Zone of Russia by using some integrated approaches. Plant Science Today. 2021;8(1):9-15. https://doi.org/10.14719/pst.2021.8.1.827 
determines their relevance. This study aimed to research the impact of integrated approaches on the improvement of the forage lands in the Central NonBlack Earth Zone. The research objectives were to develop effective technology for improving forage lands using upgraded means of mechanization, to develop effective technology for improving forage lands using upgraded means of mechanization and to determine the effectiveness of the integrated approaches implemented by assessing the productivity of forage land with the use of cultivated grass mixtures in the field.

\section{Materials and Methods}

Technologies of fundamental and simplified improvement of forage land (10) are widely used, based on a systematic approach and many years of field studies of the cultivation, grazing and harvesting of forage in meadows and pasture fields of agricultural land of the Federal State Budgetary Educational Institution of Higher Education Tver State Agricultural Academy.

The implementation of the presented machine technology was as follows. After visual observation of the field, it was divided into plots of the correct shape. After that, monitoring was conducted, photographs and videos of individual plots were obtained using the georeferenced UBSAN quadrocopter (Fig. 1). At the same time, weed vegetation was counted by the quantitative-weight method, and hillocks were counted on counting sites

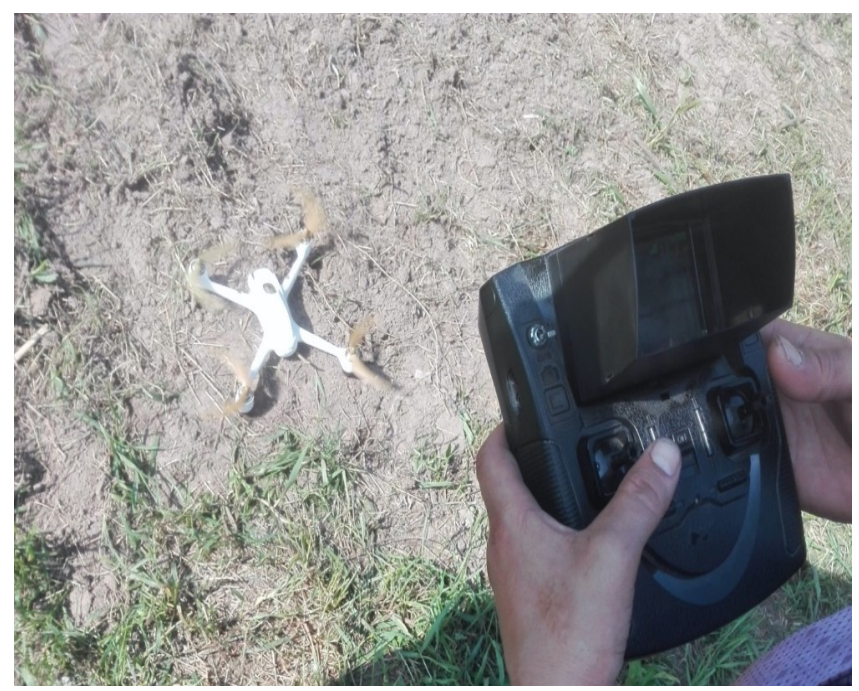

Fig. 1. Monitoring the plot using a quadrocopter.

$10 \times 10 \mathrm{~m}$ in size in three repetitions. All hillocks within the survey sites were measured for the height and diameter of the base. Individual sections bordering with ditches, floodplains and forested areas were examined using the Digma DiCam $72 \mathrm{C}$ action camera mounted on the helmet of the operator operating the Baltmotors Jam 100 ATV.

Based on the forage land monitoring with the use of various methods of examination and data processing, we formed a conclusion on the need to improve separate plots or the entire agricultural land. To assess the productivity of fodder land in the process of improvement, sowing of various grass mixtures of the target direction (hayland and pasture field) was carried out. The sowing rate of the components for each mixture was $20 \mathrm{~kg} / \mathrm{ha}$. A mixture of granular mineral fertilizers $\mathrm{P}_{20} \mathrm{~K}_{40}$ was introduced simultaneously with sowing to improve the development during the stages of germination and rooting of plants. Besides, during crop tending, top-dressing of bluegrass stands with nitrogen $\left(\mathrm{N}_{60}\right)$ fertilizers was performed during the seedling stage and spring regrowth. Phosphorus and potassium fertilizers $\left(\mathrm{P}_{40} \mathrm{~K}_{60}\right)$ were applied to all grass stands during spring regrowth.

The yield of fodder land from the selected sites was determined twice (which corresponded to two mowings and two pasturing instances) for the period of active vegetation of plants during 2015-2018 in accordance with a well-tested method (11). Accounting for the yield of dry matter was carried out on the basis of taking plant samples of green mass during mowing, then they were weighed, cut and dried in a drying cabinet at a temperature of $100-105{ }^{\circ} \mathrm{C}$ to constant weight. The percentage of moisture was determined by the formula: $\mathrm{Y}=(\mathrm{b} \times 100) / \mathrm{a}$, where a was the fresh weight, $\mathrm{g}$; $\mathrm{b}$ was the moisture loss in the sample after drying. The dry matter percentage (c) was determined by subtracting the moisture content from $100 \%$. Data on the yield of dry matter were directly obtained by the formula: $Y_{1}$ $=\mathrm{Y}_{0} \times(\mathrm{s} \times 0.01)$, where $\mathrm{Y}_{0}$ was the yield of green mass, assessed by the weight method from the registration areas.

\section{Results and Discussion}

According to the Federal Register of Technologies and Machines (12), main stages of improving forage land are monitoring of forage land, preparation of grass mixtures and mineral fertilizers, selection, setting, and tuning of machines for improvement of the forage land, direct performance of the technical process, calculation of yield, secondary monitoring of changes in forage land quality and economic assessment (Fig. 2).

If the weeds occupied more than $40 \%$ of the forage land surface or there were no valuable herbs in the plot, it was concluded that the use of the developed technology of improvement, including tillage, fertilization and sowing of grass mixtures, was necessary. Concurrently with monitoring, soil samples were taken to assess the indicators of its productivity (mobile phosphorus, exchangeable potassium, humus content, acidity), on the basis of which the conclusion was made on the need for the application of mineral fertilizers. Monitoring of fields was carried out once every three years at separate designated areas, in accordance with the field cartogram.

According to the results of the field monitoring evaluation, the necessary grass mixture for forage land improvement was prepared with regard to soil productivity. The grass mixture provides the appropriate amount of micro elements in fodder 


\begin{tabular}{|c|}
\hline $\begin{array}{c}\text { 1. Agricultural field monitoring } \\
\text { (March 20-30) }\end{array}$ \\
4. Surface improvement, \\
measurement of the process \\
quality and properties of soil \\
profile (April 20-30)
\end{tabular}

2. Preparation of grass mixtures and mineral fertilizers (April 1-6)

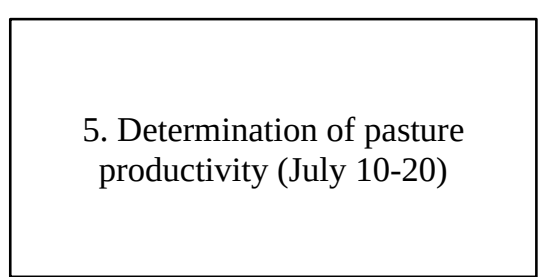

3. Setting and tuning of the machines for the improvement of the forage land (April 8-10)

6. Secondary field monitoring, technical and economic assessment (September 15-23)

Fig. 2. Machine technology for the improvement of forage land at the Federal State Budgetary Educational Institution of Higher Education Tver State Agricultural Academy.

plants, as well as the required quality and productivity. Two groups were used as grass mixtures. The first group (hayland) included Trifolium pratense L., Festuca pratensis Huds., Phleum pratense L. and Dactylis glomerata L. The second group (pasture field) included Lolium perenne L., Dactylis glomerata L., Poa pratensis L., Trifolium repens L. and Trifolium pratense L. The necessary grass mixture was prepared using screw conveyer elements, which provided reduced deformation of the seed material and increased quality of mixing with the established capacity according to the given agrotechnical requirements.

Direct surface improvement of forage land was conducted after evaluation of the soil density, bending, compressive and tensile strength to a depth of $150 \mathrm{~mm}$ using unique laboratory and field equipment from the Department of Technological and Transport Machines and Complexes (13).

During the implementation of surface improvement, we compared two technological processes - tillage and sowing (Fig. 3). The first scheme of the technological process included continuous disking of forage land to a depth of not more than $12 \mathrm{~cm}$ and sowing using a selection sowing machine $\mathrm{SN}-16$, equipped with planting runners. The second (proposed) technological scheme included the possibility of using either individual tools for sequential technological operations (rototilling,

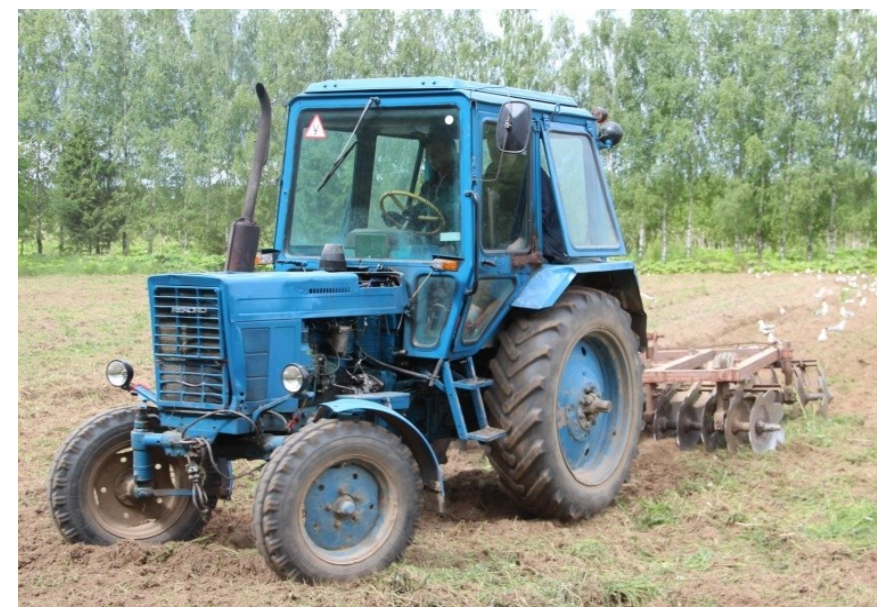

Disking mineral fertilization, sowing with the simultaneous covering, continuous post-sowing compacting) or all tools simultaneously based on combined tillage and sowing assembly.

An effective technological scheme of the functioning of the combined tillage and sowing assembly is shown in Fig. 4.

Combined tillage and sowing assembly (CTSA) was installed on a tractor of a drawbar category 1.42.0 equipped with all-wheel drive with an automatic hitch. The necessary set of tools was installed on a frame welded from hollow bars mounted asymmetrically relative to the axial longitudinal line of the tractor, which improved control over the execution of the technological process by the tractor driver.

The tillage subsystem was constructed using active tools in the form of a set of scalloped disks. Two vertical shafts were used as rotary ploughs, which were driven from the tractor's PTO through three bevel gear speed reducers. Scalloped disks were mounted on the shafts with equal distances (in the longitudinal plane) between them chosen with regard to the characteristics of the peat hillocks and weed plants to be removed. Scalloped disks fixed on the shafts rotated towards each other. When disks were lowered to the working position, they deformed the soil profile to the required depth and crushed the remains of weed vegetation.

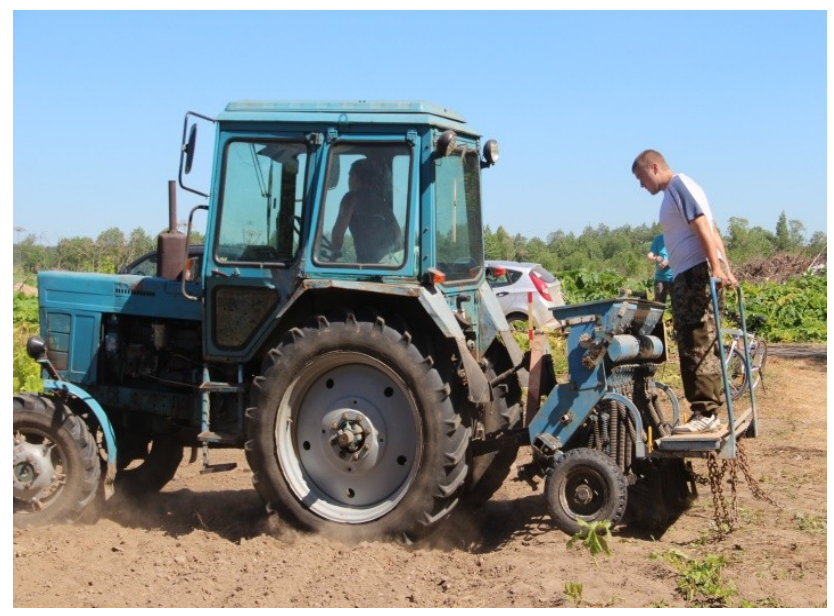

Sowing

Fig. 3. Surface improvement of forage lands. 


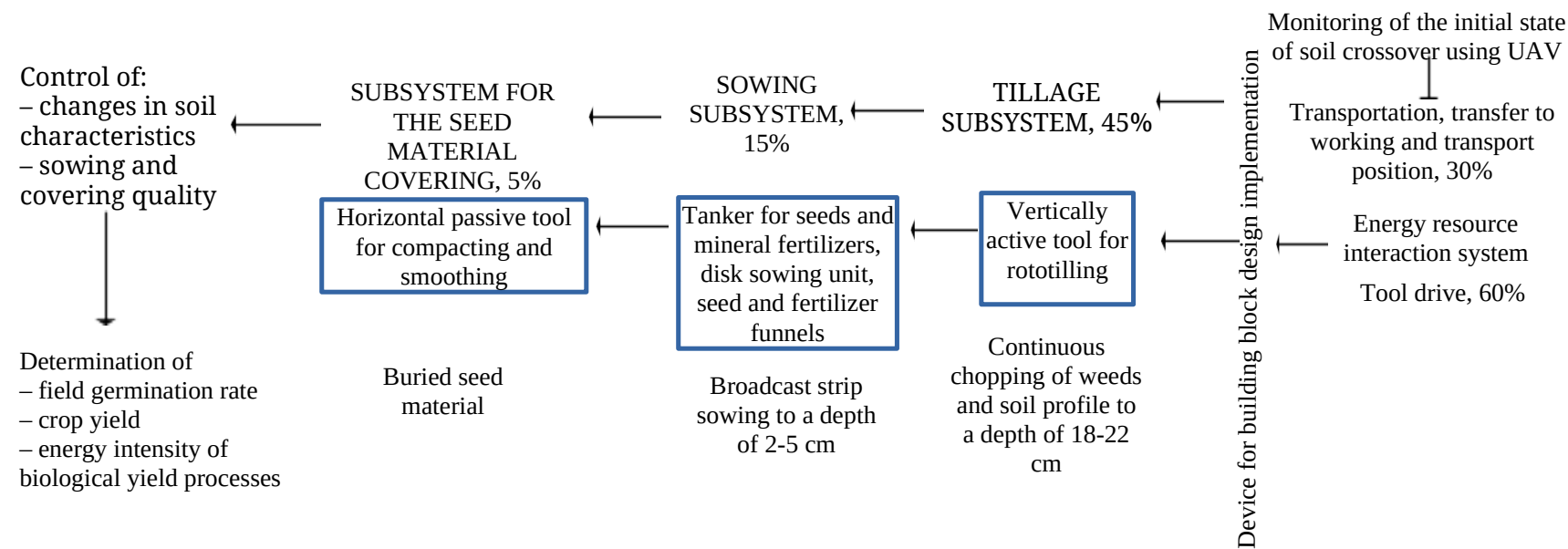

Fig. 4. Functional diagram of the technological adapter for improving forage land (percentage of energy spent on the separately performed technological process).

The disc design was hemispherical. The effective cutting area was formed by a reasonable logarithmic curve (14) that accounted for the lowest energy intensity while improving the quality of deformation of soil with weed vegetation. The cutting edge along the logarithmic curve had a sharpening angle in the range of 10-12 degrees. For the equal distribution of deformed soil aggregates and weed vegetation, the CTSA was equipped with additional passive-type leveling gear, including vertically arranged bars with an adjustable distance between them with regard to soil characteristics depending on the agrotechnical requirements. In accordance with GOST 20915-2011, the rational distance between the longitudinal bars was $3-5 \mathrm{~cm}$, depending on the initial absolute soil moisture at the epipedon.

The sowing subsystem of the technological adapter for forage land improvement included the following equipment: a tanker for grass mixtures and fertilizers, a disk sowing unit for separate sowing and fertilizing through the corresponding seed funnel and fertilizer funnel. The technological operation of sowing grass mixtures was conducted using a diffused strip method. The subsystem functioning diagram is shown in Fig. 5.

The active tool of the distributor mechanism was a horizontal disk for dosing grass mixtures and mineral fertilizers. Dosing was provided by the transition of seed and fertilizer mass through the cells of the sowing disk and sowing windows of the tanker (15). The parameters and operating modes of the distributor mechanism determined by laboratory studies and field tests allowed ensuring the fulfilment of agrotechnical requirements for the technological operation, as well as high-quality sowing with mineral fertilization (16). Adjustment of the sowing rate and rate of fertilizer application could be performed by replacing the disk of the distributor mechanism or by changing its rotation rate on an open chain drive driven by supportingdrive wheels.

The high-quality functioning of the sowing subsystem was achieved by controlling the level of filling of the tanker (fertilizer and hayseed volume control) and by providing rigid affixment of the seed and fertilizer funnels for carrying out strip-sowing and fertilizing.

Preliminary farm tests of the disk sowing unit based on a block-modular combined adapter showed the comparative advantages of a metering mechanism over analogues of Russian grass seeders (17).

The final subsystem of effective technology for forage land improvement is the covering of the seed material. A rod roller was used, which simultaneously performed not only compacting and

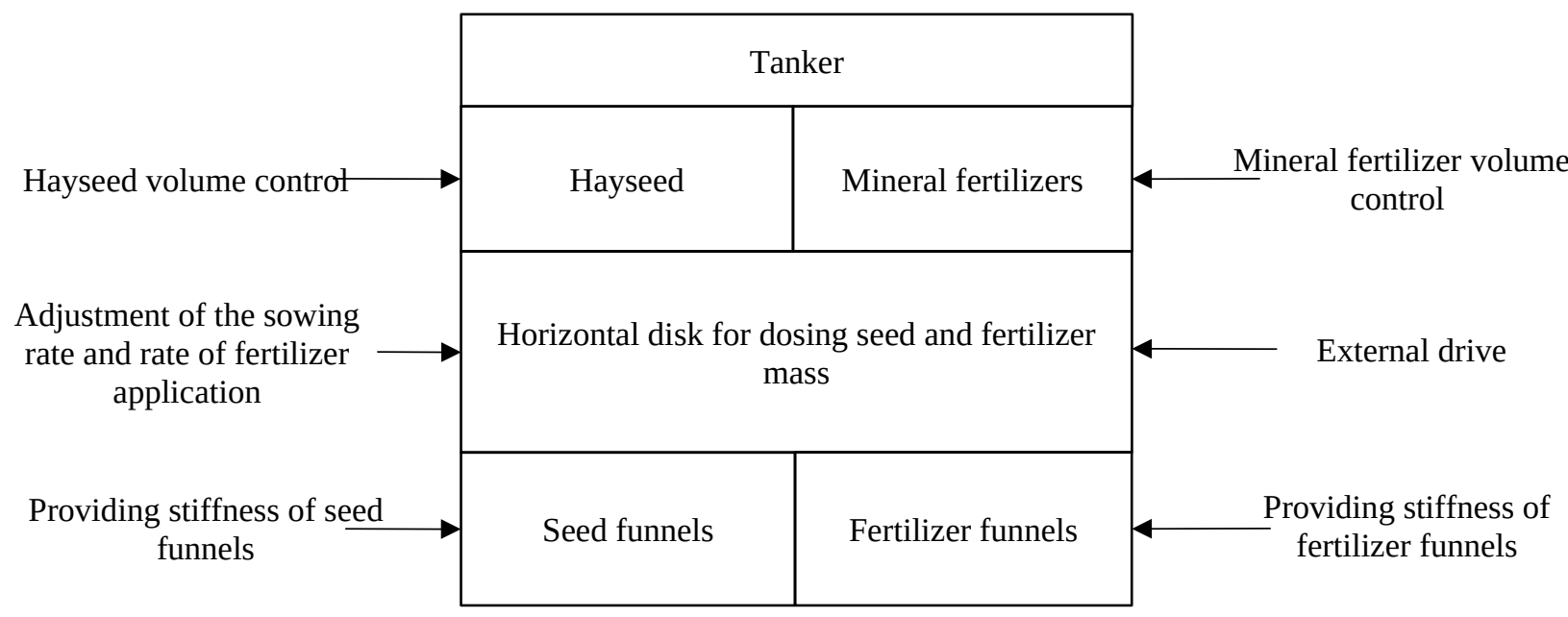

Fig. 5. Functioning diagram of the sowing subsystem. 

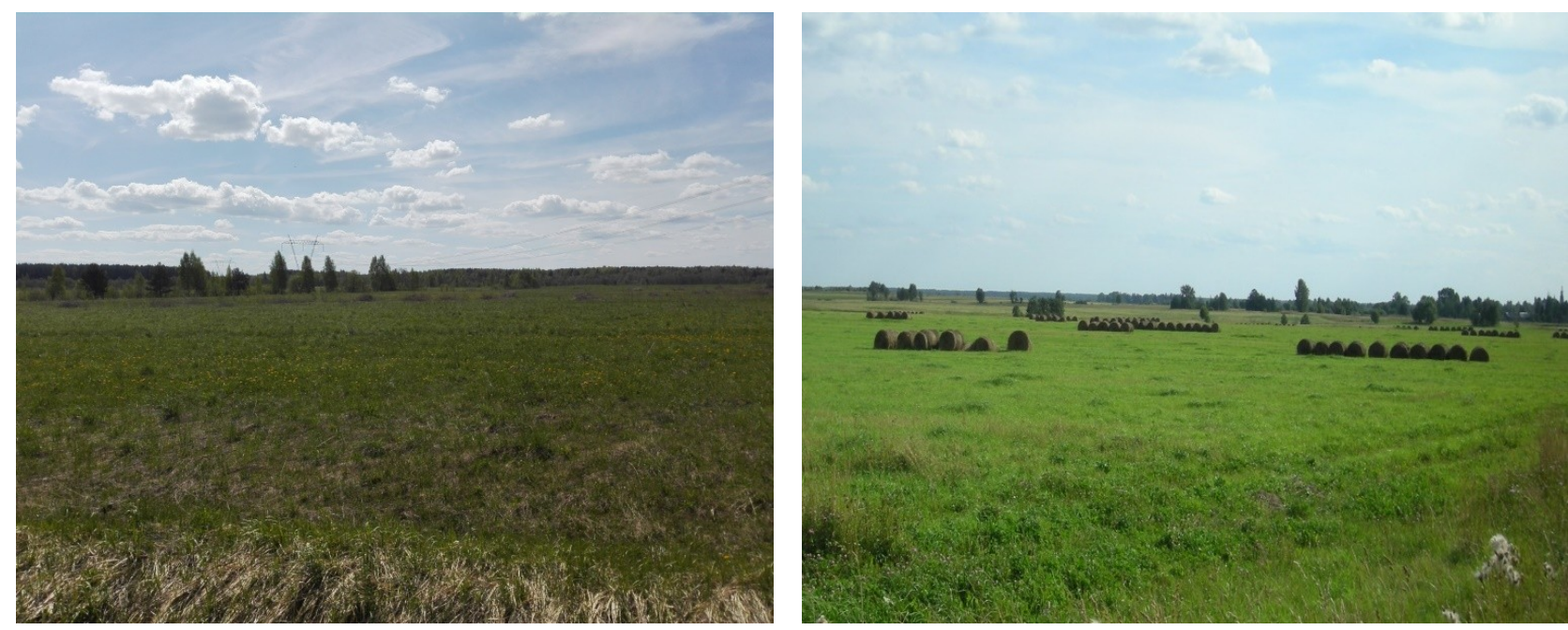

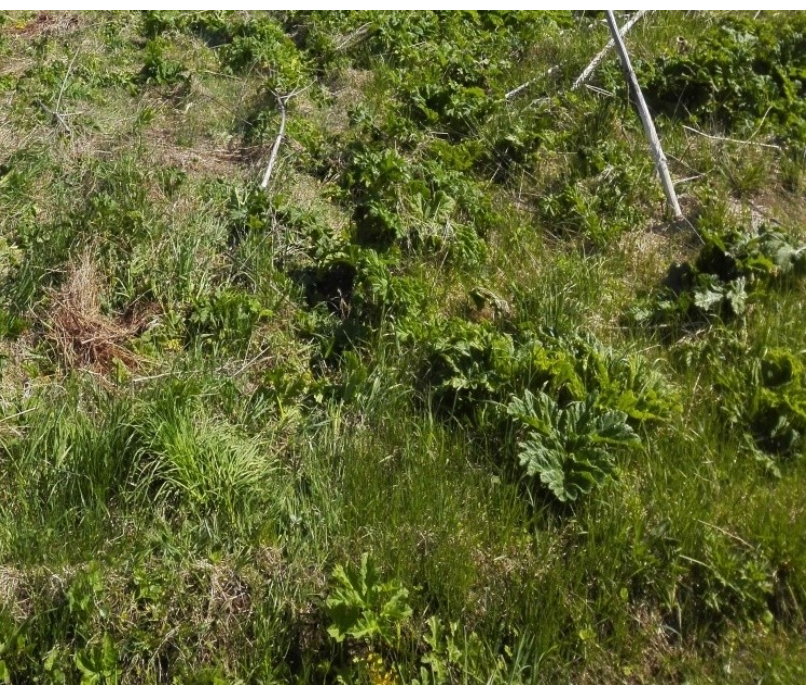

Before improvement

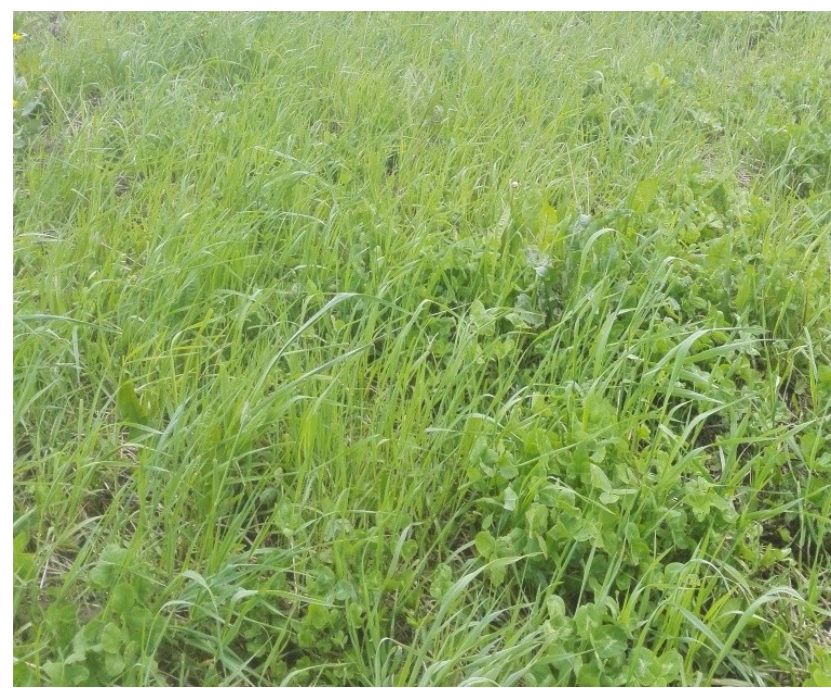

After improvement

Fig. 6. Condition of forage lands before and after improvement.

Table 1. The efficiency of using different fodder mixtures in the forage land improvement system.

\begin{tabular}{|c|c|c|c|c|c|}
\hline Tillage & $\begin{array}{c}\text { Grass mixture composition } \\
\text { (seeding rate: } \mathrm{kg} / \mathrm{mil} \text { of } \\
\text { seeds per one ha) }\end{array}$ & $\begin{array}{c}\text { Number of seedlings } \\
\text { (cereals/legumes), } \\
\text { pcs./m² }\end{array}$ & $\begin{array}{l}\text { Field germination } \\
\text { rate, } \%\end{array}$ & $\begin{array}{l}\text { The yield of dry } \\
\text { matter, } t / \text { ha }\end{array}$ & $\begin{array}{c}\text { The yield of } \\
\text { fodder units, } \\
\text { thous./ha }\end{array}$ \\
\hline \multicolumn{6}{|c|}{ Hayland improvement } \\
\hline \multicolumn{2}{|c|}{ Hayland (reference) } & - & - & 2.13 & 1.81 \\
\hline Disking and sowing & \multirow{2}{*}{$\begin{array}{c}\text { Trifolium praténse }(6 / 8) \\
\text {-Festuca pratensis }(8 / 4) \\
\text { Phleum pratense }(6 / 14)\end{array}$} & $1.251(927 / 324)$ & 48.1 & 5.12 & 4.40 \\
\hline Rototilling and sowing & & $1.418(1.012 / 406)$ & 54.5 & 5.63 & 4.84 \\
\hline Disking and sowing & \multirow{2}{*}{$\begin{array}{l}\text { Dáctylis glomeráta }(12 / 10) \\
\text { Festuca pratensis }(8 / 4)\end{array}$} & 730 & 52.1 & 4.66 & 3.68 \\
\hline Rototilling and sowing & & 813 & 58.1 & 5.05 & 3.99 \\
\hline \multicolumn{6}{|c|}{ Pasture field improvement } \\
\hline Pasture field (reference) & & - & - & 1.78 & 1.51 \\
\hline Disking and sowing & \multirow{2}{*}{$\begin{array}{l}\text { Lolium perenne }(13 / 6) \\
\text { Dáctylis glomeráta }(5 / 4) \\
\text { Poa praténsis }(2 / 8)\end{array}$} & 926 & 51.4 & 3.79 & 2.24 \\
\hline Rototilling and sowing & & 1,030 & 57.2 & 4.35 & 2.57 \\
\hline Disking and sowing & \multirow{2}{*}{$\begin{array}{l}\text { Lolium perenne }(8 / 4) \\
\text { Trifolium repens }(2 / 3) \\
\text { Trifolium praténse }(6 / 8) \\
\text { Festuca pratensis }(4 / 9)\end{array}$} & $1,222(751 / 471)$ & 50.9 & 3.16 & 2.27 \\
\hline Rototilling and sowing & & $1,343(796 / 547)$ & 55.9 & 3.78 & 2.72 \\
\hline
\end{tabular}

covering of the seed material in the surface layer but also the leveling of epipedon. The design of the soil tillage roller, which consisted of a mesh surface with different cell sizes, had a passive drive and was fixed to the frame of the technological adapter through a suspension mechanism for possible adjustment of the specific load on the soil. Grass mixtures and mineral fertilizers sowed in strips with the same row spacing were distributed over the surface of the tilled plot. The working surface of 
the mesh roller ran into soil lumps (the size of which did not exceed $5 \mathrm{~cm}$ ), deforming them with the elements of the working surface. Destroyed soil lumps not only acquired agronomically valuable dimensional characteristics in a given range but also they embedded the seed material into the soil to a small depth.

A quantitative criterion of assessing the effectiveness of the proposed CTSA is an assessment of the energy intensity of individual technological operations using GOST R52777-2007 and the necessary set of devices, including the measuring information system (IIS) IP 264, designed to measure parameters and calculate the main energy indicators of agricultural machines.

Determination of the quality of the implementation of technological processes of tillage and sowing included an analysis of the quantitative composition of agronomically valuable soil aggregates, the degree of change in the physicomechanical and technological characteristics of the soil and hillocks, and the uniformity of the distribution of the sowing grass mix and mineral fertilizers using the requirements of GOST 313452017 for testing grass seeders. After application of the roller, degree of change in the state of the soil profile and quality of the covering of seed material, as well as work of seed funnels were measured. Since the speed of the roller was in the range of 2.5$2.7 \mathrm{~m} / \mathrm{s}$, and the specific load on the soil was $1-1.3$ $\mathrm{N} / \mathrm{cm}^{2}$ on average, the density of the soil on the surface did not exceed $1.3 \mathrm{~g} / \mathrm{cm}^{3}$, and the depth of distribution of the seed material was $2-5 \mathrm{~cm}$ from the day surface of the soil. Evenness of the horizontal surface with a deviation of not more than 1-1.5 cm was observed during testing. The transformation of forage lands while mastering the developed technological approaches is clearly shown in Fig. 6.

The research results of the forage lands productivity after improvement are presented in Table 1. It has been found that the proposed soil cultivation improvement and grass mixtures significantly increased the productivity of hayfields (dry matter yield - by $2.53-3.50 \mathrm{t} / \mathrm{ha}$, fodder units - by $1.87-3.03$ $\mathrm{t} / \mathrm{ha}$ ) and pastures (by 1.38-2.57 and 0.73-1.21 t/ha respectively) compared to old-sown land.

It has been established that rototilling was the most advantageous method for fodder land improvement. By improving the quality of soil preparation, it created more favourable conditions for the formation of perennial grass productivity compared to disking. The field germination rate of hayland grass mixture seeds increased by $6.0-6.4 \%$, the yield of dry matter increased by $0.39-0.51 \mathrm{t} / \mathrm{ha}$, and the yield of fodder units increased by $0.31-0.44$ thous./ha. For pasture field grass mixture, these parameters increased by $5.0-5.8 \%, 0.56-0.62 \mathrm{t} / \mathrm{ha}$, and 0.33-0.45 thous./ha respectively. It should be noted that the found pattern was characteristic of both bluegrass and legume-bluegrass stands. The integrated application of the developed techniques provided significant increase in the productivity of fodder lands with an increase in the quality of the obtained fodder.

\section{Conclusion}

The study demonstrated the mechanism for the practical implementation of effective resource-saving technology to improve fodder land allowing to increase the efficiency of machine technology for surface improvement of fodder land and reduce energy and material costs by increasing the productivity of agricultural fields. The use of the proposed technology elements in the system for improving fodder land in the Central Non-Black Earth Zone increased not only the biological yield of harvested cultivated grass mixtures, but also the nutritional value of fodder. It was revealed that the proposed soil cultivation improvement and grass mixtures significantly increased the productivity of hayfields (dry matter yield - by 2.53-3.50 t/ha, fodder units - by 1.87-3.03 t/ha) and pastures (by 1.38-2.57 and 0.73-1.21 t/ha, respectively) compared to old-sown land. In the performed experimental studies, it was found that the developed technology for combining the technological processes of local surface tillage with sowing and cultivation almost doubled the yield of grass mixtures. The presented methodology for monitoring the condition of fodder land made it possible to increase the accuracy of the data obtained and to substantiate the necessary set of CTSA equipment when implementing the developed technology as part of an integrated approach to the improvement of fodder land in the Central Non-Black Earth Zone.

The next stage of research will be the determination of the effectiveness of the developed technology using the criterion of energy intensity.

\section{Acknowledgements}

The study was performed in the framework of the university grant, contract No. VNG-2019-5, 27.09.2019.

\section{Authors' contributions}

All authors contributed equally. All authors read and approved the final manuscript.

\section{Conflict of interests}

Authors do not have any conflict of interests to declare.

\section{References}

1. Fedorenko VF, Sapozhnikov SN, Kosolapov VM, Trofimov IA, Trofimova LS, Yakovleva EP. Innovation technologies for laying in of high-quality fodder. Moscow: FGBNU «Rosinformagrotekh»; 2017.p.196.

2. Omokanye A, Westerlund D, Lardner H, Vihvelin L, Sreekumar L. Evaluation of methods of pasture rejuvenation for improved forage production. Crop, Forage and Turfgrass Management. 2019;5(1):1-9. https://doi.org/10.2134/cftm2018.12.0103

3. Kassimova R, Adilsheev A, Mihov M. Improving technology of pastures and grasslands development. Mechanization in agriculture \& Conserving of the resources. 2019;65(3):111-13.

4. French P, O'Brien B, Shalloo L. Development and adoption of new technologies to increase the efficiency and sustainability 
of pasture-based systems. Animal Prod Sci. 2015;55(7):931-35. https://doi.org/10.1071/AN14896

5. Mocanu V, Hermenean I. Restoration of Grassland multifunctionality by direct drilling method - a solution for sustainable farming system. Romanian Agri Res. 2009;26(26):71-74.

6. Mocanu V, Hermenean I. New mechanization alternatives with low inputs for reseeding degraded grasslands. Research J Agri Sci. 2009;41(2):462-67.

7. Kumar S, Kumar N. Study on the performance of vegetative barriers and improved forage species on productivity of degraded grasslands. Int J Curr Microbiol Appl Sci. 2018;7(7):254-63. https://doi.org/10.20546/ijcmas.2018.707.030

8. Manea D, Marin E, Mateescu M, Dumitraşcu A. Theoretical and experimental research on sowing rate optimization of grassland drills. E3S Web Conf. $8^{\text {th }}$ International Conference on Thermal Equipment, Renewable Energy and Rural Development.

https://doi.org/10.1051/e3sconf/201911203003

9. Kutuzova AA, Privalova KN, Georgiadi NI (editors.) Methodology for the effective development of multivariate technologies for improving hayfields and pastures in the Northern Natural and Economic Region. Moscow: Ugreshskaya tipografiya; 2015.p.10-26.

10. Golubev VV, Kudryavtsev AV, Nikiforov MV, Gromov VV. Forage Improvement Technologies. Proceedings of the National Scientific and Practical Conference "Innovative approaches to the development of science and production of regions"; 2019 February. Tver: Tver State Agricultural Academy; 2019.p.206-08

11. Grigoreva AI (ed). Methodology of state variety testing of crops. Grain, cereal, legume, corn and fodder crops. Moscow: Kolos; 1989.p.194.

12. Kashtanova AN, Krasnoshchekova NV, Kiryushina VI. Federa Register of Crop Production Technologies. Technology system. Moscow: Informagrotekh; 1999. p.503-05.

13. Nikiforov MV, Gorbachev IV, Kudryavtsev AV, Golubev VV. The results of determination of density of soil in field conditions. Agricultural Innovation. 2018;3(28):442-47.

14. Safonov VV, Kudryavtsev AV. A method for surface improvement of hillock meadows and pastures with a device for its implementation. Patent for invention of the Russian Federation No. 2535399 dated 25.07.2013.

15. Golubev VV, Firsov AS, Rula DM. Optimization of parameters and operating modes of a disk pneumatic distributor mechanism. Forage Improvement Technologies. 2015;2:24-27.

16. Firsov AS, Golubev VV. The results of a study of parameters and operating modes of a disk pneumatic distributor mechanism for flax. Agrotechnics and Energy Supply. 2016;3(12):41-45.

17. Firsov AS, Golubev VV, Kudryavtsev AV, Safonov MA. Tests of a pneumatic distributor mechanism for flax based on a blockmodular combined adapter. Agricultural Machinery and Technology. 2017;3:35-38. 